\title{
TOWARDS CUSTOMIZED SMART GOVERNMENT QUALITY MODEL
}

\author{
Fahad Salmeen Al-Obthani ${ }^{1}$ and Ali Abdulbaqi Ameen ${ }^{2}$ \\ ${ }^{1,2}$ Lincoln University College, Wisma Lincoln, No. 12-18, Jalan SS 6/12, Petaling Jaya, Darul \\ Ehsan, 47301, Selangor, Malaysia
}

\begin{abstract}
Smart government is the next generation of the e-government that touching people closely in the perception of service quality. Although, the existing a varies of models that able to measure the level of normal quality, but there is a lack of the models that most needed for measuring the quality of Smart Government Services However, to build a smart government, it is crucial to take the quality into consideration. This paper aims o customized quality model for smart government. Building such quality model will be based on the available software quality models for smart government portals. To achieve the aims of the research, it was critical to analysis and obtain the intersection of the variable and sub variable form the key related models (McCall's,Boehm, Dromey, FURPS and the ISO 9126 Quality Model. It will consist of the most appropriate and related quality characteristics and sub characteristics. The key finding has indicated the importance of conducting practical study for proposing novel model for these purposes
\end{abstract}

\section{KEYWORDS}

SMART Government, E-Government, Quality Model

\section{INTRODUCTION}

Smart-government is also known as m-government ( $\mathrm{m}$ stands for mobile). It called m-government because it is available everywhere. The use of mobile devices such as Mobiles, Tablets, Pads, etc. is the key point the Smart Government. Therefore, the Smart Government can be referred as ' $\mathrm{m}$ Government' term.

Despite its beginning, M-Government seems to have an important effect on the creation of set of strategies and tools for E-Government strength, and on their roles and functions. The usage of mobile phones with internet connection (smartphones) is increasing quickly [1]. A very recent research report written by the UN shows that there are 1.5 billion smartphones users in the whole world which counted as about $21 \%$ of all mobile users in 2013 , and this number is increasing exponentially in many countries [2]. Nowadays, the smart mobiles are a conventional part of human daily life, and they can be used anywhere any time, and therefore, the governments in many countries around the world just provides many of their services via the internet.

In literature, M-Government has different definitions, for example, Martin et al. [3] defines MGovernment as " $a$ strategy that consist of the implementation of all kinds of wireless and mobile technologies, applications and devices for improving services delivery to the different stakeholders involved in E-Government including citizens, businesses and all government units". In addition, Sandy and McMillan [4] define M-Government as "the application of wireless mobile communication technologies of government and public-sector organizations and provision of services and sharing information to other organizations and citizens". Furthermore, Jahanshahi et 
International Journal of Software Engineering \& Applications (IJSEA), Vol.9, No.2, March 2018

al. [5] define M-Government as "a way to provide a suitable and reliable infrastructure for citizens to access services easily through providing significant tools for implementing the $M$ Government activities, thus results in giving better opportunities to people to participate in social events and activities".

Smart government can provide many services to the citizens and residents, for example. It can provide services for the following [6]:

- Health

- Education

- Security

- Filing claims and reporting problems

- Information inquiry

- Schedules

Smart government portals and applications are in turn software products. However, the "software Quality" term is defined by the IEEE [7] as "the degree to which a system, component or process meets specified requirements and customer (user) needs (expectations)". In addition, it has been defined as "conformance to explicitly stated functional and performance requirements, explicitly documented development standards, and implicit characteristics that are expected of all professionally developed software" [8]. Furthermore, ISO defines "quality" in ISO 14598-1 [9] as "the totality of characteristics of an entity that bear on its ability to satisfy stated and implied needs". In addition, it was defined as "the existence of characteristics of a product which can be assigned to requirements" [9].

In literature, there are many quality models for software products; each of such quality models contains a set of quality characteristics (attributes or factors, as called in some models). Next section will discuss the components of the following five quality models:

- McCall's Quality Model [11]

- Boehm's Quality Model $[12,13]$

- Dromey's Quality Model [14, 15]

- FURPS Quality Model [16]

- $\quad$ ISO 9126 Quality Model [17]

In this paper, the above quality models will be analyzed and discussed in order to be used in building the proposed quality model for the smart government portals and applications. However, the most related and important characteristics and sub-characteristics from these quality models will be customized and added together to form what will be called Smart Government Quality Model (SmartGQM).

The rest of the paper is organized as the following: Section 2 will discuss the related quality model the available quality models. Section 3 will introduce the proposed quality model for the smart government. Finally, section 4 will conclude the paper.

\section{Related Quality Models: An Overview:}

\subsection{MCCALL'S QUALITY MODEL}

McCall's Quality Model McCool is one of the most famous quality models in software engineering literature. It was presented by Jim McCall et al. [11]. This model stems from the US military and is primarily aimed at system developers and system development process [11]. Using 
this model, McCall tries to bridge the gap between users and developers by focusing on a number of software quality factors that reflect user views and developer priorities [11].

The McCall's quality model contains of three major perspectives (types of quality characteristics). Which can be used for defining and identifying the quality of a software product, and each of these major perspectives contains of a number of quality factors (characteristics ore attributes). However, each of these quality factors contains a set of quality criteria, and thus, each quality criteria could be replicated by one or more metrics.

McCall's Quality Model consists of:

- 11 quality factors to describe the external view of the software (from the users' view)

- 23 quality criteria to describe the internal view of the software (from the developer's view)

- Set of Metrics which are defined and used to provide a scale and method for measurement.

However, the quality factors structure of the McCall's Quality Model should provide a comprehensive quality picture of the software product [17]. The related quality metric can be measured by responding to "yes" and "no" questions. However, you will achieve 50\% on that quality criterion if you respond to equally amount of "yes" and "no" on the questions measuring it.
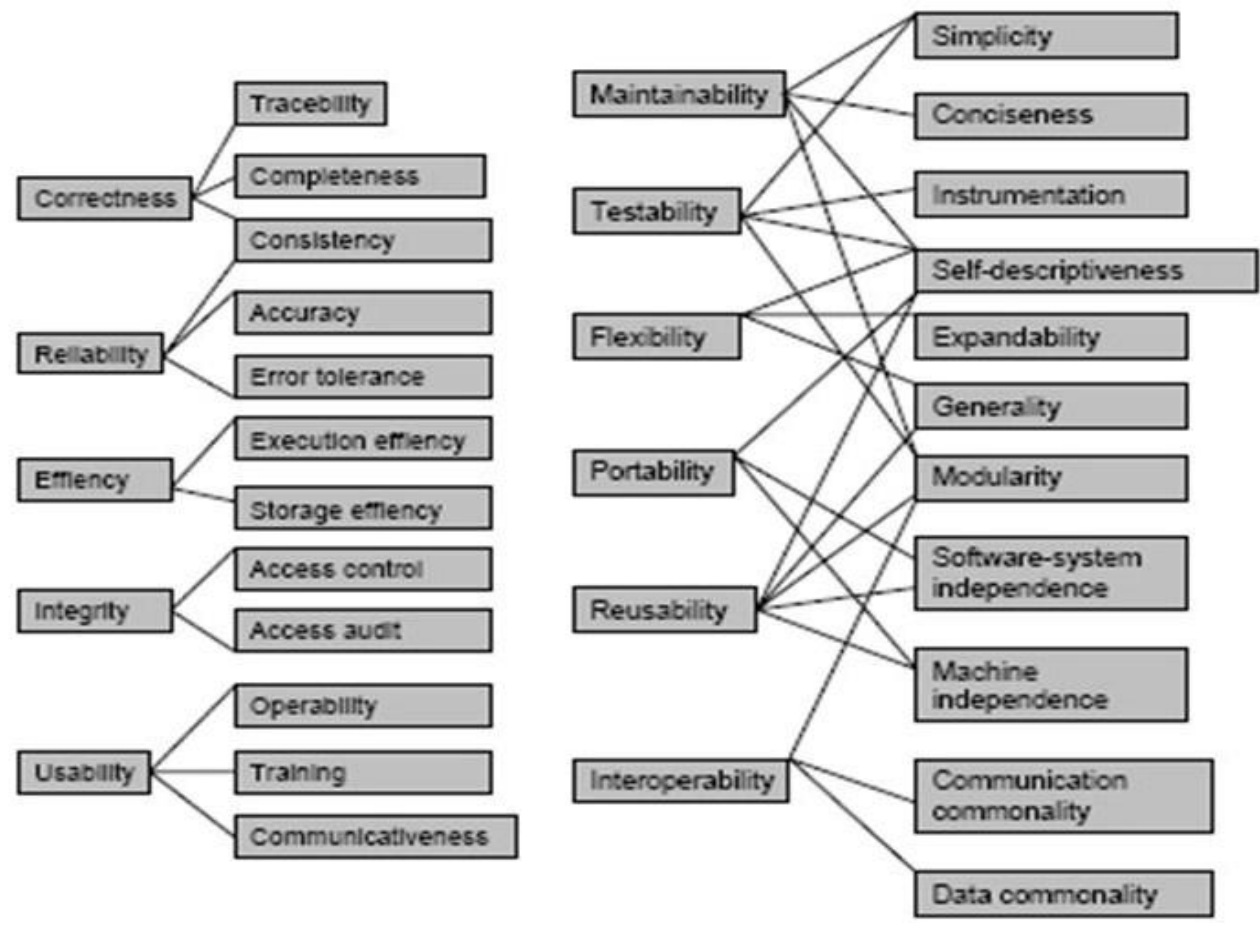

Figure 1. McCall's Quality Model [11]

\subsection{BOEHM'S QUALITY MODEL}

Boehm [12, 13] introduced his quality model to automatically and quantitatively evaluate the quality of software. This model tries to define the quality of software by a predefined set of 
attributes and metrics. Boehm quality model contains a set of characteristics of the following types (see Figure 2):

- Three High-level characteristics

- Seven Intermediate level characteristics

- Fifteen Lowest-level characteristics.

These set of characteristics can contribute to the overall quality level of software product. However, the high-level characteristics in this model represent the simple high-level requirements of actual use. In its high-level, there are three characteristics which are [12, 13]:

1. As is utility: to identify how well, easily, reliably and efficiently can we use the software product as is

2. Maintainability: to identify how easy is it to understand, modify and retest the software product

3. Portability: to identify if can we still use the software product when the environment has been changed?

High-Level Characteristics Intermediate-Level Characteristics Primitive Characteristics

\begin{tabular}{|c|c|c|}
\hline As-is Utility & $\begin{array}{l}\text { Efficiency } \\
\text { Human } \\
\text { Engineering }\end{array}$ & $\begin{array}{l}\text { Self Containedness } \\
\text { Accuracy } \\
\text { Completeness } \\
\text { Robustness/Integrity } \\
\text { Consistency } \\
\text { Accountability } \\
\text { Device Efficiency } \\
\text { Accessibility } \\
\text { Robustness/Integrity } \\
\text { Accessibility } \\
\text { Communicativeness }\end{array}$ \\
\hline Portability & & $\begin{array}{l}\text { Device Independence } \\
\text { Self Containedness }\end{array}$ \\
\hline \multirow[t]{3}{*}{ Maintainability } & Testability & $\begin{array}{l}\text { Accountability } \\
\text { Communicativeness } \\
\text { Self Descriptiveness } \\
\text { Structuredness }\end{array}$ \\
\hline & Understandability & $\begin{array}{l}\text { Consistency } \\
\text { Structuredness } \\
\text { Conciseness } \\
\text { Legibility }\end{array}$ \\
\hline & Modifiability & $\begin{array}{l}\text { Structuredness } \\
\text { Augmentability }\end{array}$ \\
\hline $\begin{array}{c}3 \\
\text { High-Level } \\
\text { Characteristics }\end{array}$ & $\begin{array}{c}7 \\
\text { Intermediate-Level } \\
\text { Characteristics }\end{array}$ & $\begin{array}{c}15 \\
\text { Distinct Primitive } \\
\text { Characteristics }\end{array}$ \\
\hline
\end{tabular}

Figure 2. Boehm's Quality Model [12, 13]

\subsection{DROMEY'S QUALITY MODEL}

Dromey's $[14,15]$ quality model was built for the software product rather than the software process. It recognizes that the quality assessment differs for each software product and that a more dynamic idea for modeling the software process is needed to be extensive enough to apply 
for different software systems [14]. However, figure 4 below shows the quality characteristics of Dromey's model.

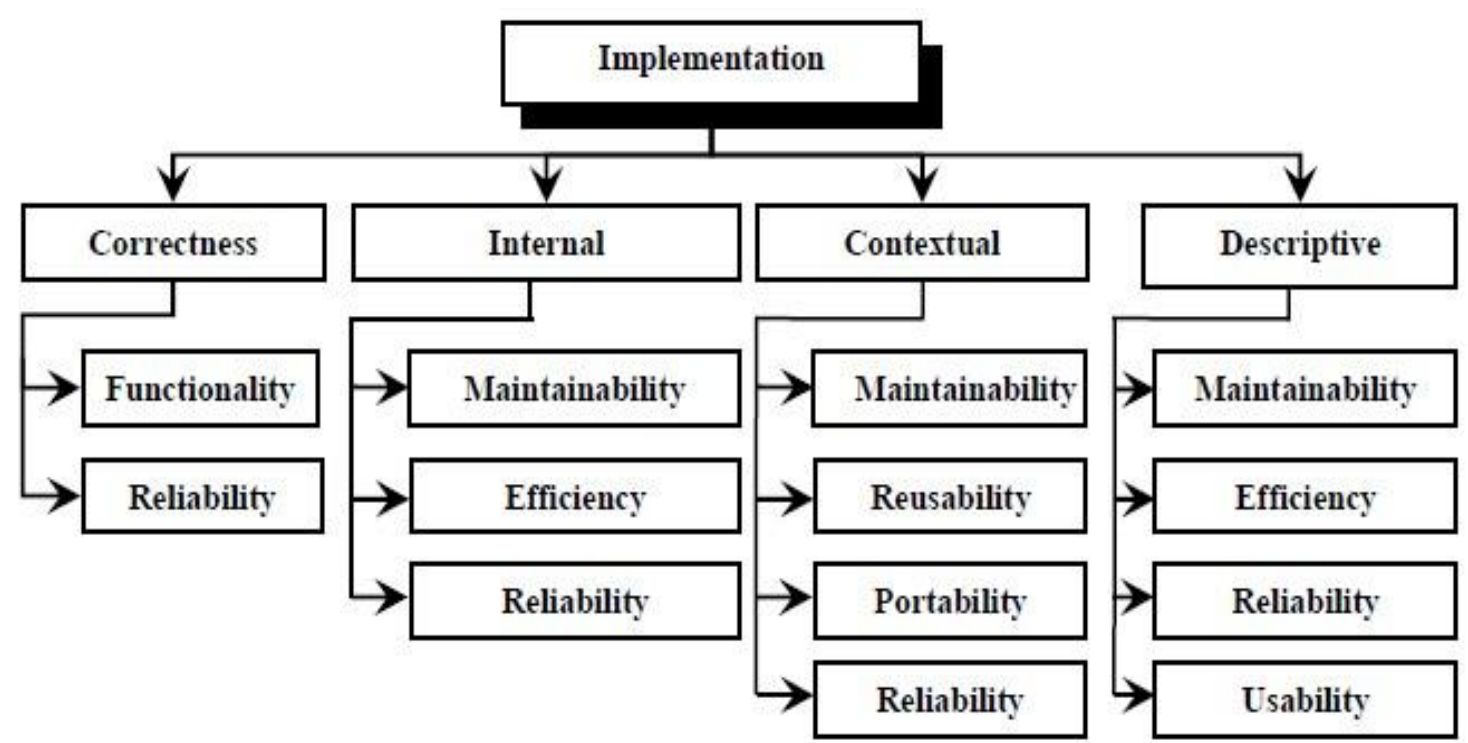

Figure 3. Dromey’s Quality Model [14, 15]

\subsection{FURPS QUALITY MODEL}

The Functional, Usability, Reliability, Performance, and Supportability (FURPS) Model firstly introduced by Robert Grady [16], then it has been enhanced and improved by IBM Company in Rational Software $[19,20]$ to becomes FURPS+, where the '+' shows such requirements as (see Figure 4 below) [19]:

- Design constraints,

- Implementation requirements,

- Interface requirements, and

- Physical requirements.

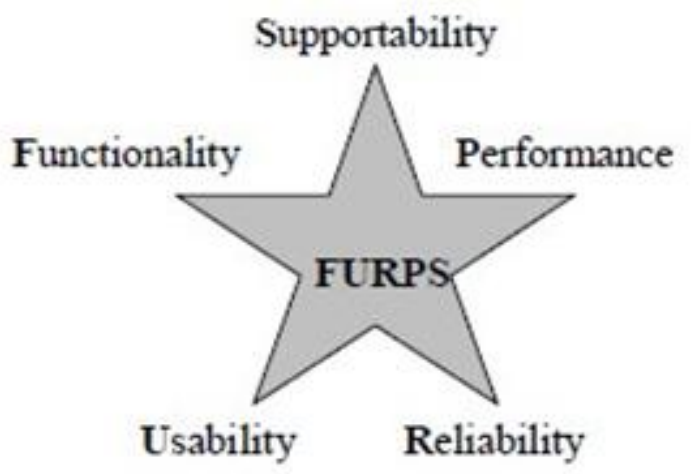

Figure 4. FURPS Quality Model [16]

Figure 5 below shows the deep contents of each characteristic of the FURPS quality model five quality characteristics 


\begin{tabular}{|c|c|c|c|c|}
\hline Functionality & Usability & Reliability & Performance & Supportability \\
\hline$\downarrow$ & 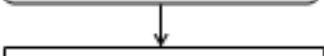 & & & $\downarrow$ \\
\hline $\begin{array}{l}\text { - Feature sets } \\
\text { - Capability } \\
\text { - Security }\end{array}$ & $\begin{array}{l}\text { - Human Factors } \\
\text { - Aesthetics } \\
\text { - Consistency } \\
\text { - Sensitive help } \\
\text { - Wizards } \\
\text { - User documents } \\
\text { - Training materials }\end{array}$ & $\begin{array}{l}\text { - Failures features } \\
\text { - Recoverability } \\
\text { - Predictability } \\
\text { - Accuracy } \\
\text { - MTBF }\end{array}$ & $\begin{array}{l}\text { - Speed } \\
\text { - Efficiency } \\
\text { - Availability } \\
\text { - Accuracy } \\
\text { - Throughput } \\
\text { - Response time } \\
\text { - Recover time } \\
\text { - Resource usage }\end{array}$ & $\begin{array}{l}\text { - Testability } \\
\text { - Extensibility } \\
\text { - Adaptability } \\
\text { - Maintainability } \\
\text { - Compatibility } \\
\text { - Configurability } \\
\text { - Serviceability } \\
\text { - Localizability }\end{array}$ \\
\hline
\end{tabular}

Figure 5. The detailed contents of FURPS quality model

\subsection{ISO 9126 QUALITY MODEL}

The International Organization for Standardization (ISO) published its first international agreement on the terminology for the quality characteristics for software product evaluation and assessment in 1991; this standard was called as "Software Product Evaluation - Quality Characteristics and Guidelines for Their Use (ISO 9126)" [17]. Next, between 2001 and 2004, the ISO introduced an extended version, containing both the ISO quality models and records of proposed measures for these models. The current version of the ISO 9126 series consists of the following:

1. ISO IS 9126-1: Quality Model [17].

2. ISO TR 9126-2: External Metrics [21].

3. ISO TR 9126-3: Internal Metrics [22].

4. ISO TR 9126-4: Quality in Use Metrics [23].

The part 1 of the ISO 9126 series - Quality Model - consists of two parts quality model for software product quality [17]; that is, internal/external quality model, and quality in use model. The first part of the two parts quality model defines six characteristics. However, each one of these six characteristics is split into twenty seven sub-characteristics for both internal and external quality (see Figure 5) [18]. The next part of the two parts model specifies four qualities in use characteristics, as in Figure 6 [17].

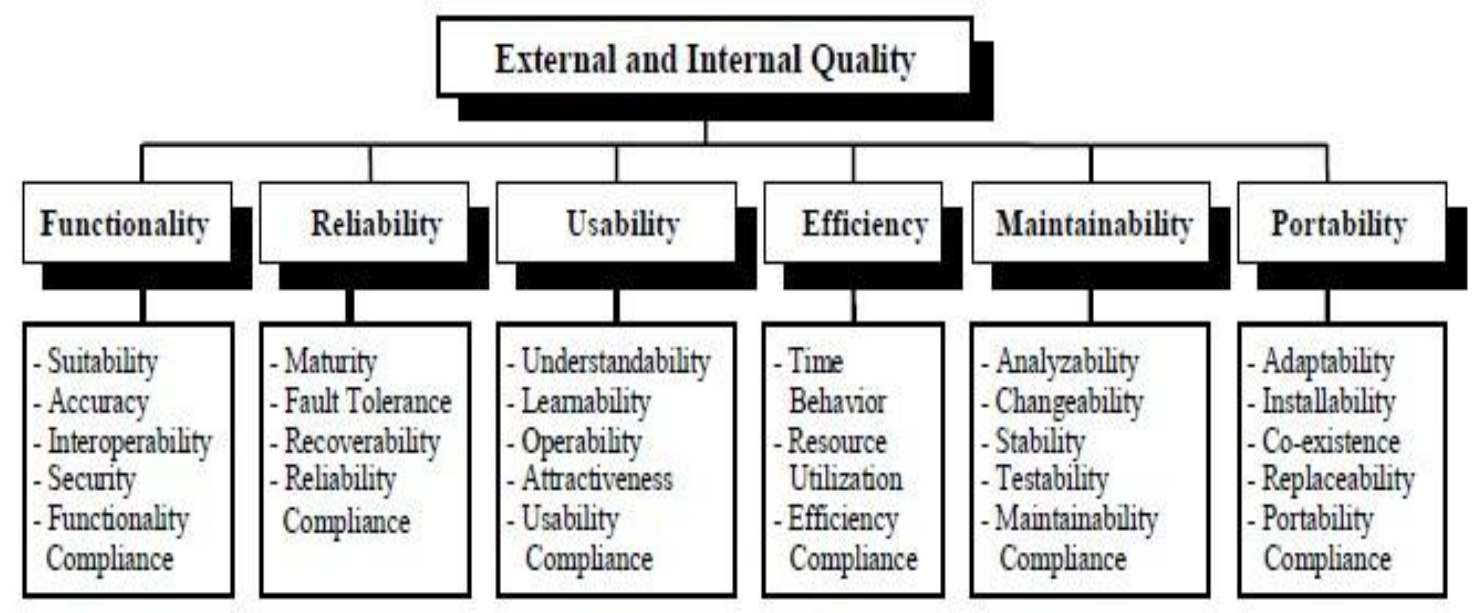




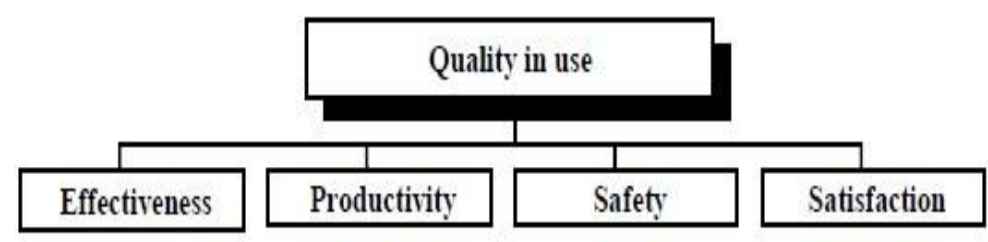

Figure 6. Quality in Use Characteristics [17]

\section{The Customized Smart Government Quality Model}

In this section, the structure of the proposed Smart Government Quality Model (SmartGQM) will be introduced. However, it will be based on the five-previous quality model (see Section 2). Figure 7 below illustrates the input resources which will be used to get the quality attributes for the proposed one.

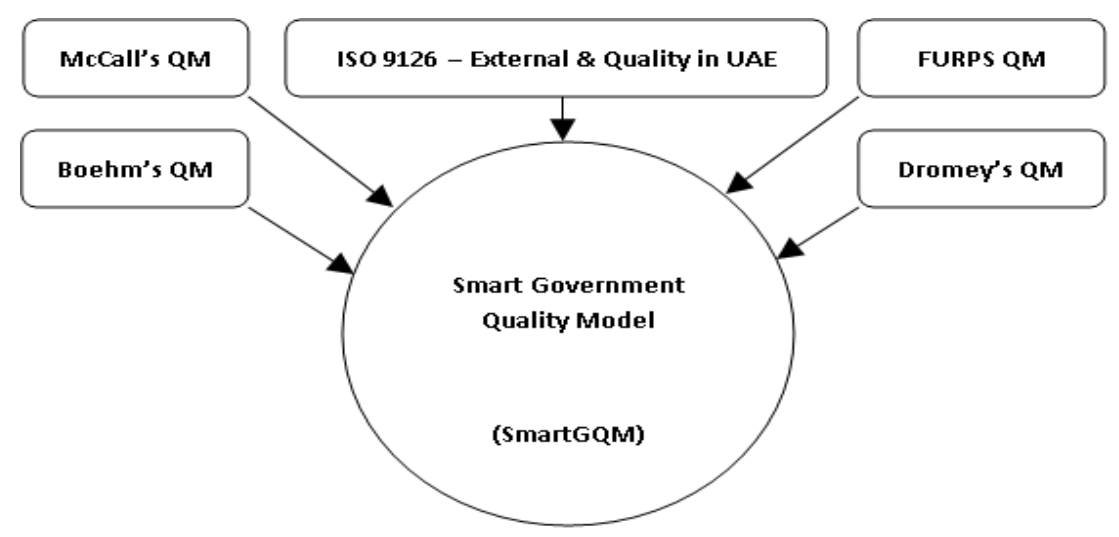

Figure 7. The inputs for the Proposed SmartGQM

The five quality models have been carefully analysed to determine which of their quality characteristics can be applied to measure the quality of the smart government portals and applications. Figure 8 below introduces the proposed contents of the Smart Government Quality Model. 


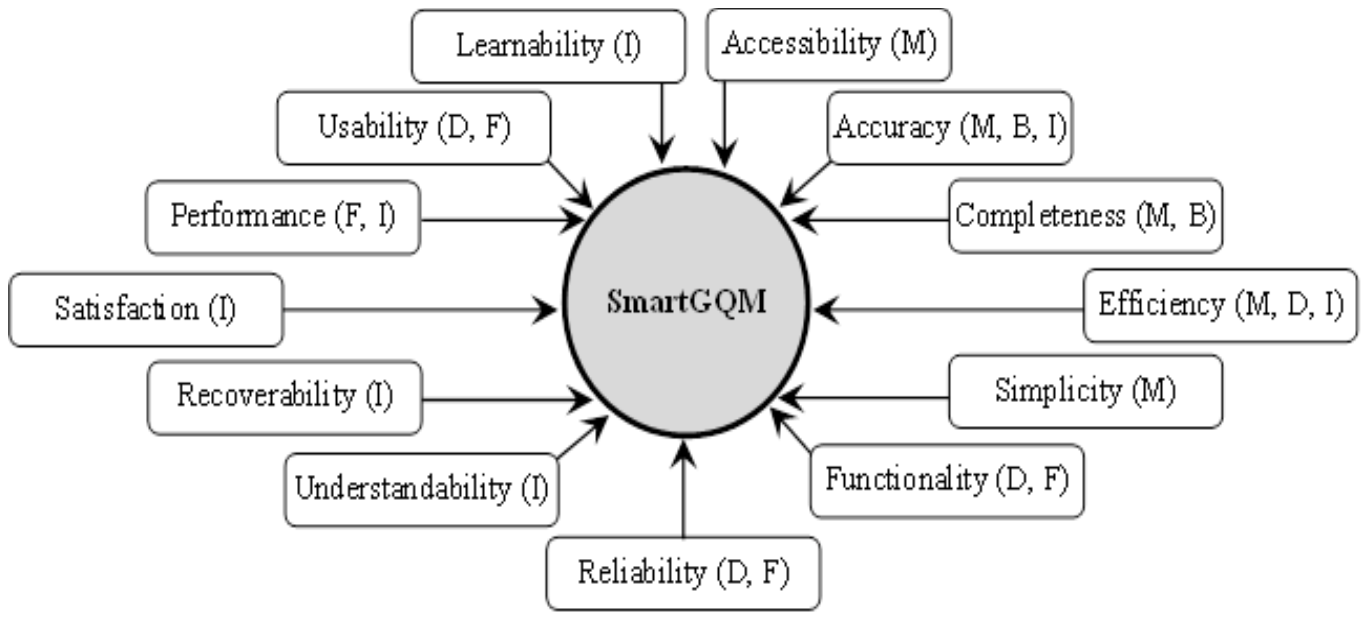
I: IOS,
M: McCall,
F: FURPS,
B: Boehm,
D: Dromey

Figure 8. Smart Government Quality Model contents

\section{Conclusions}

Smart government is the next generation of the e-government. However, in order to build a smart government portal, it is crucial to take the quality into account. In this paper, a customized quality model for smart government has been proposed, building such quality model was based on the available software quality models. The proposed quality model for the smart government portals consists of the most appropriate and related quality characteristics and sub characteristics.

The proposed Smart Government Quality model consists of 13 quality characteristics. However, these quality characteristics have been chosen from the quality characteristics of five quality models. The selection was based on the related quality characteristics which can be applied to the smart government portals and applications, and which can be determined by the end user of the smart government.

Next, in future, this Smart Government Quality model will be used to build a novel maturity model for the smart government.

\section{REFERENCES}

[1] F. S. Al-obthani and A. A. Ameen, "Toward Proposing SMART-Government Maturity Model: Best Practices, International Standards, and Six-Sigma Approach," in 1st International Conference on Management and Human Science, 2017.

[2] UN, United Nations E-Government Survey 2014: E-Government for the Future We Want. New York, USA: UN Department of Economic and Social Affairs, 2014.

[3] A. S. Martin, J. M. Gonzalez, J. A. M. Gonzalez, and V. A. M., "Use-me.gov: Usability- Driven Open Platform for Mobile Government," presented at the in Proceedings of the 2nd Open Source World Conference, Merida, Spain, 2005.

[4] G. A. Sandy and S. McMillan, "A Success Factors Model for M-Government," presented at the in Proceedings of the 9th European Conference on e-Government, Westminster Business School, University of Westminster, London, UK, 2009. 
International Journal of Software Engineering \& Applications (IJSEA), Vol.9, No.2, March 2018

[5] A. A. Jahanshahi, S. M. S. Khaksar, M. N. Yaghoobi, and K. Nawaser, "Comprehensive Model of Mobile Government in Iran," Indian Journal of Science and Technology, vol. 4, pp. 11881197, 2011.

[6] OECD, "Chapter 2: Benefits and outcomes of m-government " in M-Government: Mobile Technologies for Responsive Governments and Connected Societies, ed Paris, France: OECD Publishing, 2011.

[7] IEEE, IEEE Std. 610.12: Standard Glossary of Software Engineering Terminology. New York, NY, USA: The Institute of Electrical and Electronics Engineers, 1990.

[8] R. S. Pressman, Software Engineering: A Practitioner's Approach. New York, NY, USA: McGrawHill, 2004.

[9] ISO, ISO/IEC 14598-1: Software product evaluation - Part 1: General overview. Geneva, Switzerland: International Organization for Standardization, 1999.

[10] R. Petrasch, "The Definition of Software Quality: A Practical Approach," in Proceedings of the 10th International Symposium on Software Reliability Engineering, , 1999, pp. 33-34.

[11] J. A. McCall, P. K. Richards, and G. F. Walters, Factors in Software Quality, Volumes I, II, and III. US Department of Commerce, USA: US Rome Air Development Center Reports 1977.

[12] B. W. Boehm, J. R. Brown, H. Kaspar, M. Lipow, G. McLeod, and M. Merritt, Characteristics of Software Quality. Amsterdam, The Netherlands: North Holland Publishing, 1978.

[13] B. W. Boehm, J. R. Brown, and M. Lipow, "Quantitative evaluation of software quality," in Proceedings of the 2nd international conference on Software engineering, 1976, pp. 592-605.

[14] R. G. Dromey, "A model for software product quality," IEEE Transactions on Software Engineering, vol. 21, pp. 146-162, 1995.

[15] R. G. Dromey, "Concerning the Chimera [software quality]," IEEE Software, vol. 13, pp. 33-43, 1996.

[16] R. B. Grady, Practical Software Metrics for Project Management and Process Improvement. Englewood Cliffs, NJ, USA: Prentice Hall, 1992.

[17] ISO, ISO/IEC 9126-1: Software Engineering - Product Quality - Part 1: Quality Model. Geneva, Switzerland: International Organization for Standardization, 2001.

[18] B. Kitchenham and S. L. Pfleeger, "Software Quality: the Elusive Target," IEEE Software, vol. 13, pp. 12-21, 1996

[19] I. Jacobson, G. Booch, and J. Rumbaugh, The Unified Software Development Process: Addison Wesley, 1999.

[20] P. Kruchten, The Rational Unified Process: An Introduction: Addison Wesley, 2000.

[21] ISO, ISO/IEC TR 9126-2: Software Engineering - Product Quality - Part 2: External Metrics. Geneva, Switzerland: International Organization for Standardization, 2003.

[22] ISO, ISO/IEC TR 9126-3: Software Engineering - Product Quality - Part 3: Internal Metrics. Geneva, Switzerland: International Organization for Standardization, 2003.

[23] ISO, ISO/IEC TR 9126-4: Software Engineering - Product Quality - Part 4: Quality in Use Metrics Geneva, Switzerland: International Organization for Standardization, 2004. 
International Journal of Software Engineering \& Applications (IJSEA), Vol.9, No.2, March 2018

\section{AUTHORS}

Mr. Fahad Salmeen Al-Obthani is working as a scholarship branch director at Abu Dhabi Police in UAE. Mr. Al-Obthani has a BSc in MIS from Alain University of Science and Technology in UAE, and MBA from the Modern Sciences University in UAE. Currently, he is doing a PhD at Lincoln University College, Malaysia. His research interests are: smart government, e-government, software quality.

Dr. Ali Abdulbaqi Ameen is an associate professor and dean of College of Information Science and Multimedia at Lincoln University College, Malaysia. Mr. Ameen has a BSc degree and MSc degree from University of Mosul in Iraq, and PhD from University Kabangsaan Malaysia (UKM).

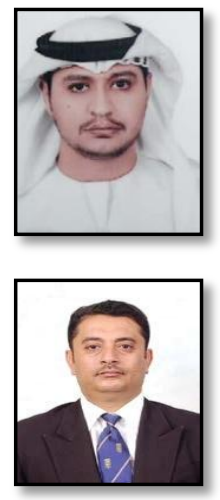

